\title{
Dirk Hofäcker (2010). Older Workers in a Globalizing World. Cheltenham: Edward Elgar, 336 pp. ISBN 9781848448179 (hardback)
}

\author{
REVIEWED by JILL MANTHORPE*
}

It is a complication of gerontology that while the ageing of the population is well known, trends in retirement are uneven and often unpredictable. In this comparison of retirement across Western developed or industrialised countries, Dirk Hofäcker presents the findings of his scholarly dissertation. The research was supported through the Volkswagen Foundation's Globalife project, and the title neatly sums up the interaction of globalisation and its contextual influences on the people in work and after retirement.

Hofäcker's thesis is that most research has concentrated on the transition from work to retirement, which may of course say much about the anxieties of researchers themselves. This is a narrow but clear furrow to plough because most people think about their own position long before the event of actual retirement and in the context of other pressures and options. Hofäcker describes such deliberations as multi-dimensional. Similarly, he argues that research on the trend to early retirement has become rather over-generalised, with vague references often being made to the economy or social trends.

This book is structured into three main parts: (1) an overview of globalisation and work in later life; (2) a macro-perspective of late careers; and (3) a micro-perspective using four countries' experiences

* Jill Manthorpe, Social Care Workforce Research Unit, King's College London, UK 
International Journal of Ageing and Later Life

(Denmark, the UK, The Netherlands and Italy). The four-country comparison enables extensive similarities to be drawn, such as the presence of labour mobility or the ability of older workers to move between employment rather than simply to cease work altogether. This close focus also reveals great differences between the countries that illustrate certain trends. These relate, not surprisingly, to social and economic influences, which can, of course, cover almost everything. The author highlights that countries that have been quick or relaxed about shedding labour may need to work harder at increasing options and opportunities for older workers since they may be taking on feelings of exclusion. Indeed he suggests that governments will need to change the perspectives of people in mid-life to have a chance of altering aspirations for early exit from employment.

Linked to this is the author's recommendation that education and training must be re-engineered to address older workers' and employers' needs to ensure a fit between older workers and employment. In his view both education and training operate within a mindset that they are preparing young people for the world of work.

There are numerous points to ponder in this book but it is not for the faint-hearted. In my view the book could have benefitted from "key points" and summary sections throughout. But, unlike many texts of such detail, it is well written and presents a wealth of data clearly. The text may be a useful resource for scholars seeking to go beyond generalisations about early retirement whether they be gerontologists, economists with interests in pension policies, or social historians who wish to investigate the perplexities of ageing societies at a time when retirement curiously seemed to be occurring earlier. 